\title{
PENERAPAN PEER LEARNING MODEL SYNDICATE GROUP DALAM MENINGKATKAN KEAKTIFAN DAN \\ HASIL BELAJAR SISWA PADA MATERI POKOK LISTRIK STATIS KELAS IX B MTS. DIPONEGORO KECAMATAN UNGARAN TIMUR SEMESTER 1 TAHUN PELAJARAN 2014/2015
}

\author{
Rumiyanto $^{1}$, Agus Sudarmanto ${ }^{2}$ \\ 1. MTs Diponegoro Ungaran \\ 2. Jurusan Fisika Fak. Saintek UIN Walisongo \\ agussudarmanto96@gmail.com
}

\begin{abstract}
Abstrak
Berdasarkan nilai ulangan harian KD sistem reproduksi dengan KKM yang ditentukan oleh guru mata pelajaran sebesar 70, hasilnya kelas IX A prosentase siswa yang nilainya tuntas adalah $79,3 \%$, dan nilai belum tuntas $20,7 \%$, sedangkan kelas IX B prosentase siswa yang nilainya tuntas hanya 40,7 \%, dan nilai belum tuntas adalah 59,3\%. Penelitian yang dilakukan adalah penelitian tindakan kelas (PTK) dengan pendekatan naturalistik yang hasil penelitian ini dipaparkan secara deskriptif. Pada silkus I keaktifan siswa secara klasikal sebesar 72,59\%, dan hasil belajar mencapai 78,52 \%. Pada siklus II keaktifan siswa secara klasikal 77,78 $\%$, dan hasil belajar mencapai 83,52 \%. Penerapan Peer Learning model Syndicate Group dapat meningkatkan


keaktifan dan hasil belajar siswa pada materi pokok listrik statis kelas IX B MTs. Diponegoro Kecamatan Ungaran Timur semester 1 tahun pelajaran 2014/2015.

Kata kunci : peer learning, syndicate group, listrik statis 


\section{PENDAHULUAN}

Pembelajaran IPA dilakukan untuk menumbuhkan kemampuan berpikir, bekerja, dan bersikap ilmiah serta mengkomunikasikannya sebagai aspek penting kecakapan hidup. Proses belajar mengajar IPA lebih ditekankan pada pendekatan keterampilan proses, hingga siswa dapat menemukan fakta-fakta, membangun konsep-konsep, teori-teori dan sikap ilmiah siswa itu sendiri yang akhirnya dapat berpengaruh positif terhadap kualitas proses pendidikan maupun produk pendidikan.

Pembelajaran IPA menekankan pada pemberian pengalaman langsung untuk mengembangkan kompetensi agar menjelajahi dan memahami alam sekitar secara ilmiah. Untuk dapat memberikan hal tersebut pembelajaran aktif merupakan salah satu teknik untuk dikembangkan dalam proses belajar mengajar. Semua anak berhak mendapatkan pembelajaran, karena dengan pembelajaran anak dapat memperoleh ilmu pengetahuan. Pembelajaran aktif adalah adanya interaksi siswa yang menyeluruh terhadap proses pembelajaran. Interaksi yang dimaksud adalah partisipasi siswa dari awal sampai 
dengan akhir pembelajaran. Peer learning (pembelajaran sebaya) adalah salah satu teknik dari pembelajaran aktif kolaboratif sedangkan syndicate group (kelompok sindikat) adalah salah satu model pembelajaran aktif kolaboratif dari metode diskusi kelompok. Dengan pemilihan teknik dan model ini diharapkan dapat meningkatkan keaktifan siswa.

Berdasarkan nilai ulangan harian KD sistem reproduksi dengan KKM yang ditentukan oleh guru mata pelajaran sebesar 70, hasilnya kelas IX A prosentase siswa yang nilainya tuntas adalah $79,3 \%$, dan nilai belum tuntas 20,7 \%, sedangkan kelas IX B prosentase siswa yang nilainya tuntas hanya $40,7 \%$, dan nilai belum tuntas adalah 59,3\%.

Berdasarkan uraian di atas, peneliti tertarik untuk melakukan penelitian tindakan kelas terhadap kelas IX B dengan pemilihan pembelajaran kolaboratif teknik peer learning (pembelajaran sebaya), metode diskusi kelompok dengan model syndicate group (kelompok sindikat) pada materi listrik statis di semester 1 tahun pelajaran 2014/2015. 


\section{METODE PENELITIAN}

Penelitian yang dilakukan adalah penelitian tindakan kelas (PTK) dengan pendekatan naturalistik yang hasil penelitian ini dipaparkan secara deskriptif. Tempat di MTs. Diponegoro Ungaran, waktu penelitaian 29 Oktober 2014 s.d. 3 Nopember 2014 dan subyek penelitiannya Siswa kelas IX B dengan kolaborator penelitian adalah Drs. Imam Sunaryo selaku Kepala Madrasah. Penelitian ini direncanakan akan dilaksanakan dalam dua siklus yang dipergunakan adalah model Kemmis \& Taggart terdapat empat tahap rencana tindakan, meliputi : Perencanaan, pelaksanaan tindakan dan pengamatan/ observasi, dan refleksi. 


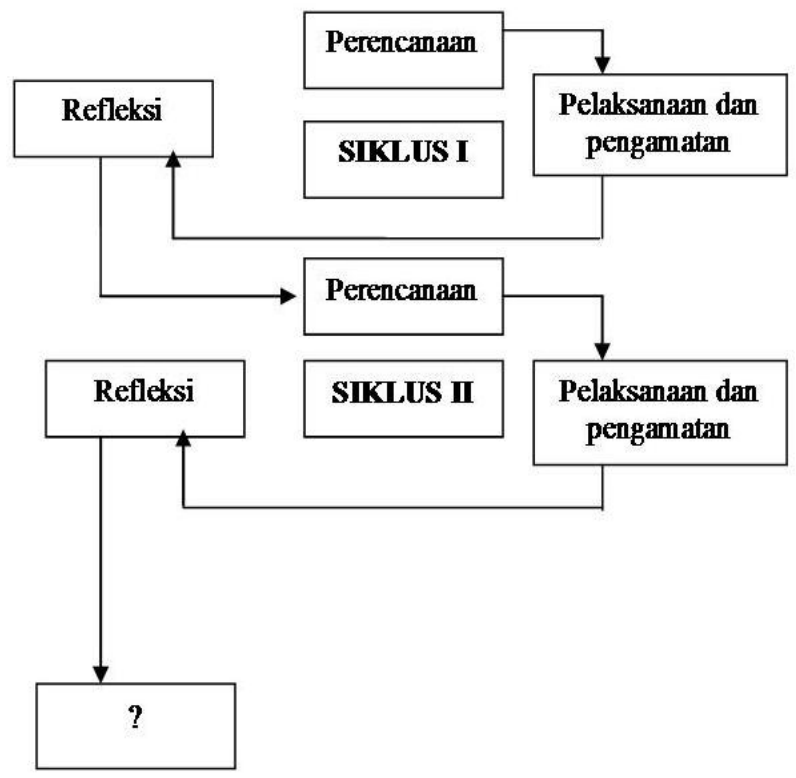

Gambar 1 Langkah siklus PTK

\section{HASIL PENELITIAN DAN PEMBAHASAN}

Siklus 1 dilakukan berdasarkan dari hasil ulangan harian yang dijadikan data sebagai pra siklus. Siklus I diperoleh hasil Hasil belajar siswa pada siklus ini. dengan hasil sebagai berikut : 


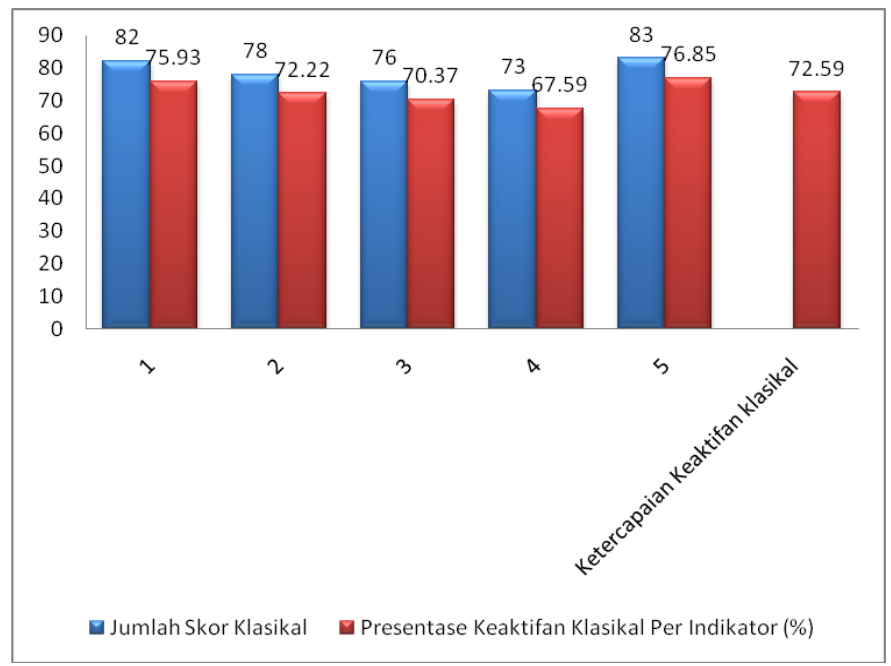

Gambar 2. Hasil siklus 1

Pengamatan pada siklus I dilakukan bersamaan dengan proses kegiatan pembelajaran berlangsung. Pengamatan difokuskan pada kegiatan pembelajaran yang ditekankan pada aspek keaktifan siswa selama kegiatan pembelajaran siklus I melalui bantuan kolaborator. 


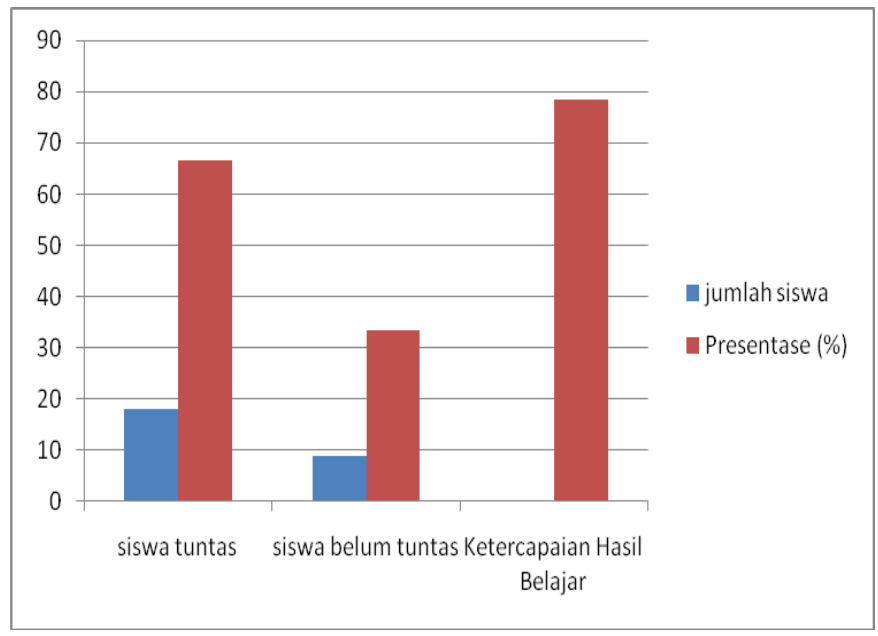

Gambar 3. Hasil siklus 1

Pada siklus I menunjukkan ketercapaian keaktifan belajar siswa 72,59 \% dan hasil belajar mencapai 78,52. Hasil analisa data ini kolaborator dengan peneliti perlu melakukan tindakan pada siklus II karena tingkat keaktifan belum mencapai $75 \%$.

Siklus II dilakukan berdasarkan hasil analisa dari siklus 1. Hasil belajar siswa pada siklus ini. dengan hasil sebagai berikut : 


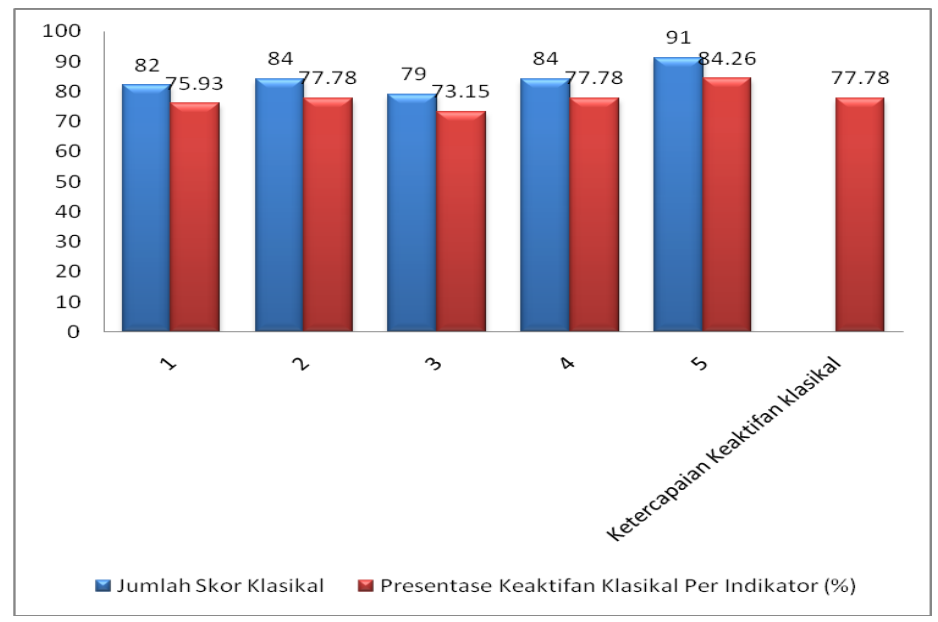

Gambar 4. Hasil siklus 1

Pengamatan pada siklus 2 dilakukan bersamaan dengan proses kegiatan pembelajaran berlangsung. Pengamatan difokuskan pada kegiatan pembelajaran yang ditekankan pada aspek keaktifan siswa selama kegiatan pembelajaran siklus 2 melalui bantuan kolaborator. 


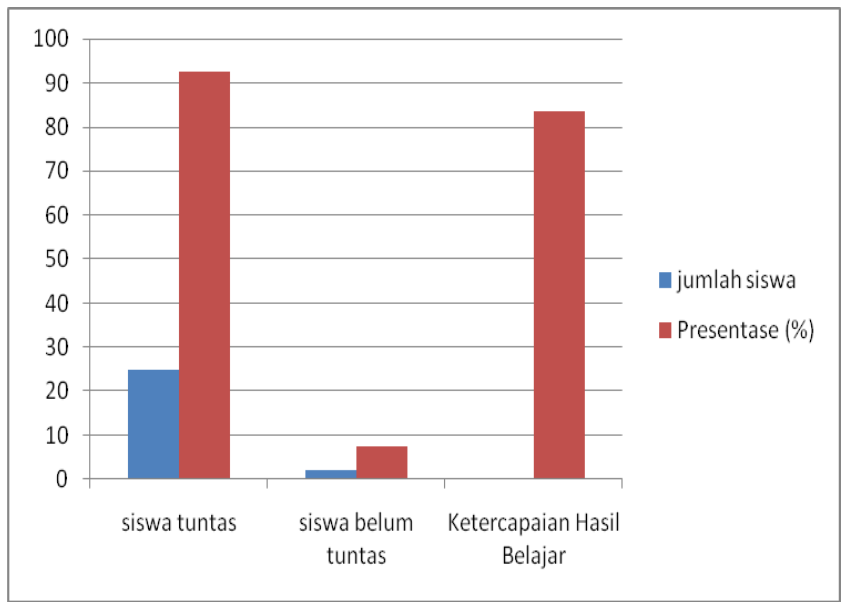

Gambar 5. Hasil siklus 1

Pada Siklus II menunjukkan ketercapaian keaktifan belajar siswa 77,78 \% dan ketercapaian hasil belajar 83,52. Dengan hasil demikian maka penelitian bersama kolaborator tidak perlu dilanjutkan ke siklus berikutnya. 


\section{KESIMPULAN}

Berdasarkan hasil analisis data dapat disimpulkan bahwa :

1. Pada silkus I keaktifan siswa secara klasikal sebesar $72,59 \%$, dan hasil belajar mencapai 78,52 \%. Pada siklus II keaktifan siswa secara klasikal 77,78 \%, dan hasil belajar mencapai 83,52\%.

2. Penerapan Peer Learning model Syndicate Group dapat meningkatkan keaktifan dan hasil belajar siswa pada materi pokok listrik statis kelas IX B MTs. Diponegoro Kecamatan Ungaran Timur semester 1 tahun pelajaran 2014/2015. 


\section{DAFTAR PUSTAKA}

Anas Sudijono, Pengantar Statistik Pendidikan, (Jakarta:

Raja Grafindo, 2003)

Persada.Arikunto Suharsimi, dkk, Penelitian Tindakan Kelas. (Jakarta: PT. Bumi Aksara. 2012)

Arikunto Suharsimi, Prosedur Penelitian. (Jakarta:

Rineka Cipta. 2010)

Budiningsih, C. A., , Belajar dan Pembelajaran, (Jakarta: PT Asdi Mahastya, 2005),

DEPAG RI, Al-Qur'an dan Terjemahnya,(Bandung:

Diponegoro, 2003)

Dimyati dan Mudjiono, Belajar dan Pembelajaran, (Jakarta : Rineka Cipta, 2009)

Ganawati, Dewi, dkk, Pembelajaran Ilmu Pengetahuan Alam Terpadu dan Kontekstual IX untuk SMP/MTs, (Jakarta : Pusat Perbukuan, Departemen Pendidikan Nasional, 2008).

Ilham, "Mengembangkan Keaktifan Belajar Siswa" http.//abangilham.wordpress.com/ . diakses tanggal 10 Desember 2015

Indriana

Kartini,

"Listrik

Statis",

httpelisal.ugm.ac.idfilescyrajehaJ7HaZ4Jr, diakses 10 Desember 2015

---- , “Teori Atom", httpelisal.ugm.ac. idfilescyrajehaJ7HaZ4Jq, diakses 11 Desember 2015

Iqtirobl Fudlla, "Penerapan Model Pembelajaran Kooperatif TGT (Teams Games Tournament) untuk meningkatkan Keaktifan Peserta Didik pada Mata Pelajaran Fisika Materi Pokok Kalor Kelas VII A MTs. NU 01 Kramat Tegal Semester Gasal Tahun Pelajaran 2011/2012", Skripsi 
(Semarang : Fakultas Tarbiyah Institut Agama Islam Negeri Walisongo,2012)

Kamus Besar Bahasa Indonesia, 2002

Modjiono dan Dimyati, Strategi Belajar Mengajar, (Jakarta : Depdikbud, 1992)

Nana Sudjana, Dasar-dasar Proses Belajar Mengajar, (Bandung : Sinar Baru Algensindo, 2002)

--- , Penilaian Hasil Proses Belajar Mengajar, (Bandung : PT Remaja Rosdakarya, 2012)

Ngalim Purwanto, Prinsip-Prinsip dan Teknik Evaluasi Pengajaran, (Bandung: PT. Remaja Rosdakarya, 2000)

Rochiati Wiriatmaja, Metode Peneliian Tindakan Kelas, (Bandung : Remaja Rosdakarya, 2007)

Semiawan, Conny, Pendidikan Keterampilan Proses, (Jakarta : Grasindo, 1992)

Siti Nur Innayah, "Pemanfaatan Alat-alat Laboratorium Fisika untuk Meningkatkan Keaktifan dan Hasil Belajar Peserta Didik Kelas XI IPA 1 MAN 1 Blora Semester Gasal Tahun Pelajaran 2010/2011 pada Materi Pokok Gerak Getaran", Skripsi (Semarang : Fakultas Tarbiyah Institut Agama Islam Negeri Walisongo, 2011)

Slameto, Belajar dan Faktor - Faktor yang Mempengaruhinya, (Jakarta : Rineka Cipta, 2003)

Sugiyono, Metode Penelitian Pendidikan Pendekatan Kuantitatif, Kualitatif dan $R \& D$, (Bandung : Alfabeta, 2010)

Suprijono, Agus. Cooperatif Learning: Teori dan Aplikasi PAIKEM. (Yogyakarta : Pustaka Pelajar. 2009) 
Suja'i, dkk, Pedoman Penulisan Skripsi, (Semarang : Fakultas Ilmu Tarbiyah dan Keguruan IAIN Walisongo, 2013)

Trianto, Model Pembelajaran Terpadu Konsep, Strategi, dan Implementasinya dalam Kurikulum Tingkat Satuan Pendidikan (KTSP), Cetakan ke-4, (Jakarta : PT Bumi Aksara, 2012)

Warsono, Hariyanto, Pembelajaran Aktif Teori dan Asesmen, (Bandung : PT Remaja Rosdakarya, 2012)

Wina Sanjaya, Strategi Pembelajaran Berorientasi Standar Proses Pendidikan.(Jakarta : Prenada Media, 2007) 